\title{
O canto XXIV e a unidade da Odisséia
}

\author{
MÍRIAM BARCELLOS GOETTEMS \\ Departamento de Letras Clássicas e Vernáculas \\ Instituto de Letras \\ Universidade Federal do Rio Grande do Sul
}

\begin{abstract}
RESUMO: A hipótese de o canto XXIV da Odisséia ser uma interpolação vem sendo defendida, ao longo dos séculos - e já desde os gregos - por diferentes estudiosos, que lançam mão de inúmeros argumentos para referendá-la. Neste artigo, arrolam-se alguns desses argumentos - mais especificamente, os apontados por Médéric Dufour e Jeanne Raison na edição da Odisséia publicada pela Difusão Européia do Livro -, buscando refutá-los através da análise de traços característicos da obra homérica presentes em XXIV; objetiva-se, assim, mostrar o estreito vínculo desse canto com os demais do poema e, por extensão, a unidade estrutural da Odisséia.
\end{abstract}

PALAVRAS-CHAVE: Homero, Odisséia, canto XXIV, unidade do poema.

A edição da Odisséia publicada pela Difusão Européia do Livro não se limita a dar a tradução propriamente dita do poema, sendo complementada por uma introdução e por diversas notas de Médéric Dufour e Jeanne Raison. Dessas notas, uma se encontra no pé da página onde inicia o canto XXIV e faz menção ao fato de que "desde Aristarco até V. Bérard, muitos argumentos de peso têm sido invocados contra a autenticidade da Rapsódia XXIV, e principalmente contra a autenticidade dos primeiros 205 versos, onde se descreve a descida à morada de Hades" (Dufour e Raison, 1960, p. 321); logo a seguir, são arrolados alguns desses argumentos, os quais se subdividem em dois grupos: aqueles que se baseiam nas "contradições existentes entre esta última rapsódia e o resto do poema" (Dufour e Raison, 1960, p. 321) e os de ordem especificamente literária, que dizem respeito às "muitas negligências e frouxidões" (Dufour e Raison, 1960, p. 322) do estilo do poeta. Ao lermos tais argumentos, de imediato sentimos o quão distante eles se encontram da realidade do poema e nos decidimos a provar, a partir deles, a nossa crença na vinculação de XXIV aos demais cantos da Odisséia e, mais ainda, na imprescindibilidade desse canto à estrutura global do poema.

Acreditamos que a melhor maneira de deixar bem claro o nosso posicionamento frente à questão é partir dos próprios argumentos que, procurando provar a inautenticidade do canto XXIV, nos levaram a um estudo mais detido de diversos elementos da obra homérica, estudo este que nos fez ficar ainda mais convictos da unidade dessa obra e, mais especificamente, da unidade da Odisséia.

O canto XXIV está, em termos de estrutura, claramente dividido em dois momentos. No primeiro deles, que se estende do verso 1 ao verso 204, encontramos Hermes conduzindo à morada de Hades as almas dos pretendentes, que lá encontram Agamênon e Aquiles a conversar; Anfimedonte, um dos pretendentes, ao ser interrogado por Agamênon, conta-lhe aquilo que ele 
próprio (Anfimedonte) chama de "o triste desfecho de nossas vidas" (Homero, 1960, p. 325); ao se inteirar dos fatos, o filho de Atreu elogia Penélope, contrapondo-a a Clitemnestra. Na segunda parte do canto, que é mais longa, pois se estende do verso 205 ao verso 547, a ação retorna a Ítaca: Ulisses vai à casa de Laertes e faz-se reconhecer pelo pai; na hora da refeição, chegam do campo Dólio e seus filhos, que, ao reconhecerem Ulisses, enchem-se de alegria; nesse ínterim, divulgouse a notícia do morticínio, e Eupites, pai de um dos pretendentes mortos, marcha contra Ulisses, seguido de seus partidários; Atena consulta Zeus, que manifesta o desejo de que a paz volte a reinar em Ítaca; trava-se a batalha, e Eupites morre; Atena intervém e reconcilia os dois partidos.

Seguindo essa estrutura bipartida do canto, os argumentos de que lançam mão os estudiosos, para provarem a sua crença na inautenticidade de XXIV, também se subdividem em duas categorias: aqueles que se voltam contra a autenticidade da primeira parte, ou seja, da descida aos Infernos, e os que têm por fim negar a autenticidade da segunda parte, isto é, da visita de Ulisses ao pai e da luta contra os partidários dos pretendentes.

Cremos ser mais lógico seguir também essa bipartição em nosso estudo e, por isso, dedicarnos-emos, em primeiro lugar, aos argumentos que dizem respeito à descida ao Hades. Dentre eles, salientaremos, inicialmente, aqueles que tomam por base as supostas contradições existentes entre alguns elementos narrados na primeira metade do canto e o restante do poema.

Eis o primeiro desses argumentos: "Em nenhum outro passo da obra homérica Hermes é o deus cilênio, nem o condutor das almas, nem tem na mão a varinha de ouro" (Dufour e Raison, 1960, p. 321). Tomar esse fato como prova de que o canto não é autêntico é uma atitude que, a nosso ver, desconhece o modo pelo qual o poeta apresenta suas personagens: Homero jamais as descreve, fazendo-as emergir das próprias ações que realizam e revelar-se através delas; a soma das revelações graduais, proporcionando-nos uma visão plurilateral da personagem, é que nos dá a imagem completa da mesma. Isso, aliás, constitui um objetivo marcante do poeta épico: ele quer trazer para diante de nossos olhos aspectos múltiplos da realidade, e, como o homem faz parte dessa realidade, ele quer, em consequiência, trazer para diante de nossos olhos aspectos múltiplos do homem. Onde se lê "homem", pode-se, sem problema algum, ler "deus", pois o deus homérico também é parte integrante da realidade. Ora, se Homero, procurando fugir à reiteração, apresenta notas caracterizadoras das personagens nas mais diversas circunstâncias, não é de surpreender que só agora Hermes se nos apresente como o deus condutor das almas ao Hades. Seria de estranhar, isto sim, se Homero fizesse referência a essa atribuição do deus num momento em que ela fosse totalmente desnecessária; nesse caso, teríamos excelente motivo para colocar em dúvida a qualificação de artista normalmente atribuída a Homero.

Podemos fazer uso, para ratificar nossa posição, destas palavras de Robert Aubreton: "Os cantos mais discutidos não deixam de mostrar-nos os heróis sob novos ângulos, essenciais à sua compreensão (...)" (Aubreton, 1968, p. 188). E o que Aubreton diz dos heróis pode ser aplicado a todas as personagens homéricas, inclusive os deuses. Há uma preocupação constante no narrador de completar a imagem das suas personagens, de fugir ao padronizado, apresentando, em cada situação (mesmo que seja no último canto do poema), elementos ainda desconhecidos, o que satisfaz, em última análise, ao seu desejo, tão claramente manifesto, de abarcar a realidade na sua extrema variedade.

O segundo argumento, que também se refere à chegada de Hermes ao Hades com os pretendentes, diz o seguinte: "É uma multidão de mortos ainda não enterrados. Em nenhum outro passo os defuntos são admitidos na morada de Hades senão depois de terem sido sepultados" (Dufour e Raison, 1960, p. 321-2). Contrapormo-nos a esse argumento exige que retrocedamos ao canto XI, onde ocorre a conhecida evocação dos mortos: acontece que a primeira alma a aparecer a Ulisses, nessa evocação, é justamente a de Elpenor, cujo corpo ainda não havia sido sepultado. Pode-se contra-argumentar observando que Ulisses não chega a descer ao Hades, que são as almas que vêm ter com ele. Isso é verdade, mas não há indicação alguma de que a alma de Elpenor não tenha vindo, junto com as demais, "do fundo do Érebo" (Homero, 1960, p. 149), como o narrador diz. Por outro lado, depois de contar a Ulisses os pormenores de sua morte, Elpenor afirma explicitamente: "(. . .) quebrei as vértebras do pescoço e minha alma baixou à morada de Hades" (Homero, 1960, p. 150 - grifo nosso). Atente-se bem para o fato de que esse testemunho parte de 
um morto cujo corpo ainda não havia recebido as honras fúnebres costumeiras e o sepultamento, coisas que, aliás, Elpenor pede a Ulisses que faça "para que eu não suscite contra ti o ressentimento dos deuses" (Homero, 1960, p. 150). As palavras de Elpenor são a comprovação de que não há, em Homero, a crença de que a alma, antes de ter sido enterrado o corpo, não possa penetrar no Hades; o máximo que se pode dizer é que o sepultamento é condição precípua para que ela, a alma, possa encontrar o repouso na existência (se é que podemos chamá-la assim) depois da morte. Essa busca de repouso é que, na verdade, recebe ênfase maior, o que pode ser verificado pelas próprias palavras de Elpenor acima transcritas, através das quais ele ameaça Ulisses com o "ressentimento dos deuses" se não lhe der sepultura condigna.

$O$ terceiro argumento levantado contra a autenticidade da primeira parte do canto XXIV diz respeito à menção feita por Agamênon, no seu diálogo com Aquiles, às noves Musas: "Só aqui Homero fala de um número determinado de Musas" (Dufour e Raison, 1960, p. 322). Tal argumento parece-nos ainda mais inconsistente do que os anteriores, e, se procurarmos penetrar mais profundamente na intenção do poeta nos trechos em que ele se refere às Musas, veremos que há uma boa dose de lógica na sua postura, aparentemente contraditória, frente ao número delas.

Para comprovar nossa opinião, devemos recorrer ao proêmio da Odisséia: "Canta para mim, ó Musa, o varão industrioso que (...)" (Homero, 1960, p. 11). A invocação à Musa e não às Musas que Homero aí faz não deve ser entendida como crença do poeta na existência de apenas uma destas divindades, mas como uma forma indireta de pedir às nove Musas que, ao atuarem como suas inspiradoras, não o façam cada uma por si, individualmente, mas como um todo ordenado, como um conjunto que tenha em mente um objetivo comum; esse voltar-se de todas as suas "coautoras" para um mesmo fim é que poderá possibilitar ao poeta transmitir à sua obra um cunho de verdade e, mais ainda, de unidade.

Por outro lado, no trecho que serve de base ao argumento acima transcrito, lemos: "Em seguida, as nove Musas entoaram em tua honra um treno de coplas alternadas (. . .)" (Homero, 1960 , p. 324). Enquanto, no trecho examinado anteriormente, o poeta esperava das Musas uma ação conjunta e una, o que possibilitava a sua visão como um todo, aqui encontramos as Musas agindo, se não individualmente, pelo menos em subgrupos, o que fica transparente pelo fato de elas estarem entoando um "treno de coplas alternadas". A ação de inspirar o poeta deveria ser una para que também o seu produto fosse uno, mas a ação de cantar, que, por si só, já nos traz à mente a noção da existência de vozes diferentes (como num coral), não só pode como deve ser atribuída às nove Musas.

O quarto e último dos argumentos desse grupo refere-se também a um deus: "Dioniso não aparece no resto da Odisséia, a não ser uma vez no desfile das mulheres (XI, pág. 156), o qual, por seu turno, é também de autenticidade muito suspeita" (Dufour e Raison, 1960, p. 322). A resposta a esse argumento é dada por Aubreton ao discutir a suposta divisão dos poemas homéricos em partes "antigas" e partes "recentes". Diz o referido estudioso a esse respeito:

"Poderá ser contestada a antigüidade de certas passagens em que se faz menção de Dioniso. Victor Bérard, entre outros, dirá no comentário do canto XI da Odisséia: 'Uma particularidade trai a época tardia desta interpolação ateniense: o deus Dioniso aqui aparece; ele não figura em nenhuma outra parte nos versos autênticos dos poemas'. Por que essa condenação? Porque se supôs, em princípio, que tal culto era posterior ao periodo homérico. E essa afirmação se baseia, por sua vez, no fato de que não se encontra menção desse deus nos versos chamados 'autênticos' dos poemas!!... De fato, é um culto que remonta ao período préhelênico, e as últimas leituras das lâminas de Pilos e de Cnossos provam que, no século XIV a.C., Dioniso já era conhecido" (Aubreton, 1968, p. 61).

Melhor resposta do que essa não temos condições de dar.

Examinemos agora os argumentos de ordem literária que são igualmente invocados contra a autenticidade da primeira parte do canto XXIV.

O primeiro deles refere-se ao diálogo entre Agamênon e Aquiles - mais especificamente, ao momento em que o filho de Atreu diz que Tétis, ao tomar conhecimento da morte do filho, "saiu das 
águas em companhia das imortais deusas marinhas, e por sobre as ondas ecoou um grito imenso, que fez estremecer todos os Aqueus. Estes teriam corrido a refugiar-se em suas bojudas naus, se os não tivesse contido Nestor (...)" (Homero, 1960, p. 323). O argumento diz o seguinte: "É, pelo menos, estranho que os Aqueus se tenham assustado com as lamentações das deusas marinhas, a ponto de terem querido fugir para as suas naus" (Dufour e Raison, 1960, p. 322). Eis um argumento que só pode ter partido de alguém que se negue a reconhecer que as personagens homéricas não são tipos e sim indivíduos e que, como tais, estão sujeitas a todas as emoções, inclusive o medo. A esse respeito, afirma Donaldo Schüler: "Na Ilíada, não há personagens planas. Nem todas as personagens estão caracterizadas. (. . .) Mas logo que Homero caracteriza, aparecem personagens esféricas, ou personagens que se aproximam da esfericidade" (Schüler, 1972, p. 75). E logo a seguir:

"Tanto os aqueus como os troianos se distinguem por um heroísmo legendário. Todos, porém, não só os troianos, se mancham da maior vileza, acometidos de medo, em certas ocasióes fogem do inimigo.

“A primeira vez que Homero põe o ouvinte/leitor em contato com o exército aqueu, mostra-o em fuga. (. . .) 'A prova de uma personagem esférica é a sua capacidade de nos surpreender de maneira convincente.' Vale para o exército o que Forster afirma da personagem" (Schüler, 1972, p. 75).

O que Schüler diz, referindo-se à Ilíada, vale para toda a Odisséia e, com propriedade surpreendente, adapta-se a esse episódio do canto XXIV, em que o narrador, por meio da fala da personagem, se reporta a acontecimentos da guerra de Tróia, o pano de fundo da llíada.

Homero não cria tipos: suas personagens nos surpreendem com suas atitudes, pois, heróis que são em muitos momentos, não deixam de assumir características anti-heróicas em outros. E é justamente com a criação de personagens complexas e imprevisíveis que Homero consegue alcançar a densidade humana. O herói grego, considerado quer individualmente quer como membro de seu grupo, é sempre visto numa dimensão humana: ele é covarde, sente medo, e isso porque ele é homem e não super-homem.

O segundo argumento levantado também diz respeito ao diálogo entre Aquiles e Agamênon, o qual é qualificado de "ridículo e inverossímil" (Dufour e Raison, 1960, p. 322): "Por que motivo Agamémnon, encontrando Aquiles na morada de Hades, teria esperado quase dez anos, antes de pensar em falar-lhe de seu funeral?" (Dufour e Raison, 1960, p. 322-3). Embora tão sem fundamento quanto os demais, se levado em consideração todo o processo homérico de criação artística, esse argumento exige, para ser refutado, um pouco mais de penetração no referido processo. Para iniciarmos esta penetração, vejamos o que diz Aubreton com referência não ao diálogo em análise especificamente mas a todo o contexto em que ele se insere, isto é, a descida ao Hades: "Porque na Odisséia se encontra três vezes a cena da Tapeçaria de Penélope ou duas Descidas aos Infernos, julga-se que só uma é primitiva" (Aubreton, 1968, p. 63). E já que foi mencionada a tela de Penélope, cremos ser melhor transcrever também o terceiro argumento de ordem literária levantado contra a autenticidade da primeira parte do canto XXIV, argumento esse que vem ilustrar as palavras de Aubreton: "A história, uma vez mais relatada, da tela de Penélope, não passa de um enchimento canhestramente encaixado no conjunto da rapsódia" (Dufour e Raison, 1960, p. 323). Tentaremos provar que não é bem assim e que tanto a segunda descida aos Infernos como a terceira menção a Penélope e sua tela devem ser consideradas não como interpolações mas sim como partes essenciais da narrativa.

Relembremos um dos primeiros parágrafos da Odisséia - mais especialmente, a primeira fala de Zeus no poema: o pai dos deuses e dos homens faz referência, nessa ocasião, ao destino de Agamênon, que, ao retornar de Tróia, encontrara a morte nas mãos de Egisto, amante de sua mulher, Clitemnestra; esse crime, que ficara impune durante muitos anos, fora agora vingado por Orestes, único filho homem de Agamênon e de sua esposa. Acreditamos que uma pessoa que esteja lendo a Odisséia pela primeira vez e desconheça o seu enredo, deve ficar se perguntando sobre os motivos que levaram o autor a colocar na boca de Zeus palavras aparentemente tão 
desligadas do núcleo básico do poema. Perguntas desse tipo não ficam, no entanto, muito tempo sem resposta; na verdade, o diálogo que, em seguida, encetam o pai dos deuses e dos homens e sua filha Atena mostra-nos claramente o porquê da menção feita a Agamênon: diz a deusa que partirá para Ítaca a fim de estimular o filho de Ulisses e "incutir-lhe no coração energia bastante para que convoque na ágora os Aqueus de longa cabeleira e expulse todos os pretendentes (...)" (Homero, 1960, p. 15 - grifo nosso). Até o leitor mais desatento poderá concluir que a história de Agamênon relatada por Zeus não está tão dissociada, como parece num primeiro momento, da de Ulisses; há, pelo menos, duas semelhanças bem marcantes entre os dois heróis: ambos têm a felicidade conjugal ameaçada e um único filho homem; e, ao se dar conta disso, o leitor facilmente compreende que a história de Agamênon tem, na Odisséia, uma função exemplar: pode acontecer com Ulisses o mesmo que aconteceu com o filho de Atreu. Por outro lado, fica-se também ciente da importância atribuída a Penélope nesse poema: a sorte de Ulisses depende muito da atuação de sua esposa em relação aos pretendentes; se ela for uma segunda Clitemnestra, não há grandes chances para o herói, que, então, terá de contar unicamente com sua astúcia para salvar-se da morte certa; mas, se, mantendo a fidelidade ao esposo (e aqui ganha relevo o relato da tela de Penélope), ela se recusar a aceitar um segundo casamento, o herói poderá, então, reconquistar o seu lugar de esposo e de rei.

A incerteza quanto aos verdadeiros sentimentos e intenções de Penélope não permanece no leitor durante muito tempo; ainda no canto I, nós a encontramos dizendo ao aedo Fêmio: " ' (...) põe fim a essa triste rapsódia, que sempre me tortura o íntimo do coração, desde que sobre mim veio um luto inconsolável. Grande é a saudade que sinto de um ente tão querido, e inextinguível a recordação do herói, cuja glória se espalha ao longe através da Hélade e paira sobre Argos' “ (Homero, 1960, p. 21).

A confirmação da sinceridade dessas palavras vem no canto II, com o relato feito por Antino do ardil imaginado por Penélope - o da tela - para protelar o mais possível uma decisão que não lhe agrada tomar. A verificação que esses dois episódios nos permitem fazer da fidelidade de Penélope traz uma questão nova sobre os motivos que levaram o narrador a relembrar a história de Agamênon. Expliquemo-nos melhor: embora não possamos negar a função educativa da mesma, parece-nos, já no canto II, ser pouco provável que vá acontecer com Ulisses o que aconteceu com o Atrida. Se isso é assim, devemos procurar outra causa para a importância atribuída pelo poeta ao destino de Agamênon. Quer-nos parecer que essa causa se encontra em um processo formal adotado por Homero na elaboração de seus poemas, que é o de salientar os contrastes existentes entre situações e personagens. A introdução da história de Agamênon possibilita ao narrador a apresentação de diversas oposições, no que se refere tanto ao caráter das personagens como ao tipo de existência por elas levada. Dentre essas oposições, a que mais se salienta é a existente entre Clitemnestra e Penélope. A esse respeito, diz Aubreton: "À Penélope fiel que sabe repelir os pretendentes, o poeta opõe, desde o início do poema, Clitemnestra que trai o esposo (. . .)" (Aubreton, 1968, p. 215). A mesma opinião é expressa por Médéric Dufour e Jeanne Raison: "A esposa de Ulisses, a prudente Penélope, opõe-se à esposa infiel - senão verdadeiramente culpada - Helena, que na Ilíada é causa inicial da guerra, e também à esposa conjugicida, Clitemnestra, que assassinará o Atrida vencedor de Tróia, quando esse regressa ao lar (...)” (Dufour e Raison, 1960, p. 9).

Observe-se, nessa citação, a ampliação do contraste, colocando-se também Helena como exemplo de infidelidade conjugal. Mas detenhamo-nos especificamente na oposição entre Clitemnestra e Penélope. A importância dada a ela é tão grande que o narrador a menciona em quatro momentos diferentes no decorrer do poema: ao primeiro deles já nos referimos, isto é, à fala de Zeus no canto I (o contraste aqui não fica muito evidente porque ainda não entramos em contato com Penélope); depois Nestor, no canto III, narra longamente a cena cruenta do assassínio de Agamênon no palácio de Argos; a terceira referência à atuação contrastante de Clitemnestra e Penélope ocorre no canto XI, com o elogio feito à esposa de Ulisses por Anticléia e, em particular, com as palavras de Agamênon (aliás, a fala do Atrida vem comprovar a opinião emitida anteriormente sobre a pouca ou, melhor, nenhuma possibilidade de vir a acontecer com Ulisses o que sucedeu a Agamênon; diz ele que Ulisses pode vir a ser morto, mas que, se o for, não o será "por 
tua mulher, porque ela, a filha de Icário, a cordata Penélope, é muito sensata e nutre justos propósitos em seu espírito" - Homero, 1960, p. 159); por fim, no último canto, a partir de uma nova fala de Agamênon, é estabelecida novamente a antítese entre as duas esposas. É importante observarmos como essa técnica adotada por Homero de oposição de caracteres consegue realçar as qualidades de Penélope e, de modo todo especial, a sua fidelidade, que, no fim, lhe dá a felicidade.

Ao falarmos sobre o processo homérico de opor situações e caracteres, demonstrando-o através da constante antítese entre Clitemnestra e Penélope, defrontamo-nos com o motivo pelo qual não podemos considerar a segunda descida aos Infernos uma interpolação: tal cena é importante e necessária à unidade estrutural da Odisséia porque, através dela, o poeta fecha o círculo das oposições que havia iniciado já no canto I do poema. A primeira dessas oposições cremos já ter sido suficientemente explorada nos parágrafos acima. Examinaremos agora outras que também figuram na mencionada cena.

Podemos referir-nos, em primeiro lugar, ao contraste existente entre Ulisses e os companheiros que, com ele, estiveram na guerra de Tróia. Esse contraste manifestara-se no canto I: "Encontravam-se já na pátria todos os outros heróis que, na guerra ou sobre as ondas do mar, haviam escapado à morte violenta. Ulisses era o único que todavia ansiava pelo regresso e pela esposa, retido como estava em gruta profunda pela veneranda ninfa Calipso, deusa entre as deusas, que ardia no desejo de o tomar como esposo" (Homero, 1960, p. 12).

O que se observa no canto XXIV é uma certa ampliação desse contraste, pois, além de contrapor Ulisses a Agamênon, herói que, embora assassinado logo depois do regresso, havia escapado à morte violenta "na guerra ou sobre as ondas do mar", o narrador o opõe também a Aquiles, um dos heróis que morreram na própria guerra. Não obstante as diferenças entre os dois tipos de morte, Agamênon e Aquiles estão agora em pé de igualdade: ambos são habitantes do Hades, do mundo das sombras, e se opõem a Ulisses, pois este permanece na vida. Hades e vida são coisas opostas: "(. . .) o que importa para Homero é a matéria e a vida na matéria, a existência além túmulo não merece o nome de vida" (Schüler, 1972, p. 26). "A morte é negação da vida, é a escuridão que contradiz a luz." (Schüler, 1972, p. 27.) O quanto essa existência no Hades desagrada ao homem fica bem claro nas palavras proferidas por Aquiles no canto XI: "(. . .) 'Ilustre Ulisses, não tentes consolar-me a respeito da morte; preferiria trabalhar, como servo da gleba, às ordens de outrem, de um homem sem patrimônio e de parcos recursos, do que reinar sobre mortos, que já nada são! (...) " (Homero, 1960, p. 160).

Essas palavras, cuja amargura "traduz as saudades sem esperança do homem que abandonara a luz do dia" (Pereira, 1967, p. 104), exprimem todo o horror do homem grego pela nãoexistência e ratificam a oposição entre Aquiles-Agamênon e Ulisses: este é muito mais feliz do que aqueles, pois, conseguindo, sobreviver à guerra e reconquistando o devido lugar ao lado da esposa, é um homem que faz parte da matéria, da vida, desta vida que "se realiza plenamente apenas neste mundo visível, múltiplo e belo" (Schüler, 1972, p. 27).

Compreendendo o início do canto XXIV como uma continuação do processo homérico de contrapor personagens, podemos facilmente explicar o porquê da narração da morte de Aquiles. Vimos que esse herói e Agamênon opõem-se a Ulisses, de modo todo especial pelo fato de este ainda viver enquanto aqueles já fazem parte do mundo das sómbras; acontece que nós já sabemos como Agamênon foi parar nesse mundo - Nestor o relatou a Telêmaco no canto III -, mas desconhecemos como Aquiles morreu; a narração de sua morte no canto XXIV, embora cronologicamente numa posição discutível, é necessária para que a oposição entre os dois heróis mortos, de um lado, e Ulisses, do outro, fique completa, realçando ainda mais, com a tristeza que dessa narração emana, a felicidade de Ulisses.

Embora a chegada dos pretendentes aos Infernos seja importante para possibilitar ao narrador uma palavra final sobre as oposições Clitemnestra x Penélope e Agamênon-Aquiles $x$ Ulisses, não é apenas nesse fato que reside a causa de sua colocação no poema. Essa chegada é importante não somente como meio mas como fim em si mesma, pois, através dela, completa-se a imagem que, desde o início da obra, vínhamos tendo dos pretendentes. Nesse sentido, devemos observar que Anfimedonte, apesar de dizer "quero porém contar-te sinceramente e em pormenor o triste desfecho de nossas vidas" (Homero, 1960, p. 325), encaminha o relato para outro lado, 
procurando eximir-se o quanto possível de suas culpas: ele não faz menção, por exemplo, aos prejuízos por eles causados a Ulisses durante o tempo em que desfrutaram dos bens dele e muito menos à emboscada que prepararam contra Telêmaco; e, além de não ser sincero, só conta "em pormenor" os episódios que podem conferir aos pretendentes uma aura de vítimas, inclusive deturpando-os (nova falta de sinceridade), como é o caso do episódio do arco, que ele relata como uma manobra imaginada por Ulisses com o apoio da esposa. Olhando as coisas por este ângulo, acreditamos ser incorreto dizer, como lemos no argumento antes transcrito, que a história da tela de Penélope "não passa de um enchimento canhestramente encaixado no conjunto da rapsódia". Essa história, além de possibilitar uma última antítese entre Clitemnestra e Penélope, tal como demonstramos anteriormente, serve para que Anfimedonte, como porta-voz dos pretendentes, caracterize de modo ainda mais vivo a personalidade do grupo: são jovens inconsequientes, insinceros, que não hesitam em retirar de seus ombros o peso de suas culpas, atirando-o a outrem. Como diz Woodhouse, o episódio da tela, tal como o conta o pretendente, possui uma importância que, na verdade, não lhe é atribuída na Odisséia (Woodhouse, 1930, p. 117).

Retornando ao processo homérico de oposição de caracteres, podemos observar que a pequenez dos pretendentes, bem evidenciada no relato de Anfimedonte, contrasta com a aura de grandeza que cerca os heróis que combateram em Tróia. Por outro lado, se voltarmos a uma idéia antes emitida sobre as semelhanças existentes entre Agamênon e Ulisses, particularmente no que se refere à ameaça que paira sobre a felicidade conjugal de ambos, poderemos concluir que há um outro contraste entre os pretendentes e os dois heróis e, ao mesmo tempo, uma semelhança entre os primeiros e Egisto: os pretendentes e Egisto constituem a ameaça a que nos referimos acima; a única diferença entre eles é que Egisto triunfou sobre sua vítima, a ameaça que ele representava chegou a se tornar realidade, ao passo que, no caso dos pretendentes, foram eles que se tornaram vítimas - mas não vítimas de Ulisses e sim de seus próprios crimes. "A hybris dos pretendentes é expiada com a morte", afirma Werner Jaeger (Jaeger, s.d., p. 75), o que traduz a existência, na Odisséia, de uma irreparável ligação do destino com as culpas humanas. Com a chegada dos pretendentes ao Hades, a expiação de suas culpas atinge o clímax: é a chegada a um mundo sem luz, a um mundo sem vida, e o quanto isso desagradava ao homem grego já o demonstramos antes.

Parece-nos estranho que um estudioso como Aubreton chegue a dizer que "a Descida ao Inferno não pode ser conservada", pois é "uma interpolação final que atendia ao desejo dos ouvintes de saber o que aconteceu com os diversos heróis de Tróia" (Aubreton, 1968, p. 349). Cremos ter conseguido provar nossa opinião de que as coisas não são bem assim e que o início do canto XXIV faz parte do processo homérico de apresentação de personagens através de antíteses, processo esse que se evidencia já no canto I do poema.

Detenhamo-nos agora nos argumentos relativos à segunda parte do canto XXIV, ou seja, a que narra a visita de Ulisses a Laertes e a luta contra os partidários dos pretendentes, com a obtenção final da paz. Os argumentos invocados contra a autenticidade dessa segunda metade do canto são especificamente de ordem literária.

O primeiro deles diz o seguinte: "Tais narrativas são feitas por meio de fórmulas banais, estereotipadas, sem qualquer alento vital" (Dufour e Raison, 1960, p. 323). Recorrer ao uso que o narrador faz de fórmulas estereotipadas para provar a inautenticidade do último canto da Odisséia parece-nos atitude de quem, se levou em consideração os cantos anteriores, não deu a devida atenção ao fato de que tais fórmulas se encontram disseminadas por todo o poema, constituindo uma das características fundamentais da linguagem épica. Realmente, "o verso épico está cheio de fórmulas feitas, que aparecem sem cessar" (Aubreton, 1968, p. 82). O porquê da repetição das mesmas é múltiplo, podendo ser visto sob vários ângulos: segundo alguns, tais fórmulas são meios mnemotécnicos para uso do declamador, que, enquanto as pronuncia, pode pensar no que lhes deve seguir (Aubreton, 1968, p. 83); de acordo com outros, elas se impõem para satisfazer necessidades métricas (Schüler, 1972, p. 22, e o próprio Aubreton, 1968, p. 85); outra opinião - e esta é a que mais de perto nos interessa no momento - é a de que tais fórmulas "prendem o poeta ao mundo exterior em que ele com absoluta preferência se movimenta. (...) Apresentam um mundo constante, fixo, não conturbado pelas emoções e simpatias do poeta" (Schüler, 1972, p. 22-3). 
Cremos encontrar, nessas palavras de Donaldo Schüler, a resposta para a acusação de falta de "alento vital" na última parte da Odisséia: acontece que o poeta épico está voltado para fora, para o objeto (e as fórmulas estereotipadas, como bem o diz Schüler, auxiliam-no a se manter nessa posição), não se concentrando, em momento algum, no mundo subjetivo de suas personagens. $\mathrm{O}$ autor épico não interfere emotivamente nelas e trata todos os seus sentimentos dentro de uma perspectiva objetiva, o que, sem dúvida, pode, às vezes, nos deixar com uma certa impressão de falta de humanidade nessas personagens. Porém, se esta interpretação que estamos dando à falta de "alento vital" a que o autor do mencionado argumento se refere, está correta, devemos observar que tal falta não se restringe apenas ao último canto da Odisséia, mas, bem ao contrário, é característica de todo o gênero épico; nesse sentido, basta lembrar o encontro entre Ulisses e Penélope, em que verificamos a ausência de uma relação mais subjetiva entre o casal; e, se um tal tipo de relação não existe entre marido e mulher, por que deveria existir entre pai e filho? Se não existe em nenhum dos casos é simplesmente pelo motivo já exposto: o poeta épico não está interessado em disposições e tendências subjetivas. "Ele não conhece absolutamente os estados d'alma, senão como 'ocorrências' ou 'acontecimentos'." (Staiger, 1975, p. 84.) Sua atenção está presa no objeto, e, sendo ele "um poeta que tudo contempla e a si mesmo apresenta, não há de ocupar-se muito tempo com os domínios interiores, já que eles, de qualquer modo, só dificilmente são representados como objetos" (Staiger, 1975, p. 85). interior:

Diz Donaldo Schüler a propósito do posicionamento do homem homérico frente ao mundo "O homem homérico sabe de um mundo interior, sabe que acontecem coisas em si,
mas esse mundo não lhe é claro, não o fascina, não se demora nele. (. .) O homem
homérico é incapaz de uma análise psicológica, porque não tem noção de reali-
dades psicológicas. Volta-se para fora, para o mundo visível, luminoso, concreto,
único verdadeiramente real. (. ..) As qualidades e os sentimentos do homem só se
manifestam quando se confrontam com o mundo exterior" (Schüler, 1972, p. 43-4).

A mesma opinião é defendida por Jaeger quando diz que Homero "nunca considera os homens em abstrato e apenas na sua intimidade. Tudo se passa no quadro plenário da existência concreta. (...) A sua [das personagens] existência está em íntima conexão com o mundo exterior, pela coerência do pensamento e da ação" (Jaeger, s.d. p. 76).

No que respeita a essa última citação, é particularmente elucidativo o encontro de Ulisses com Laertes, no decorrer do qual os sentimentos do ancião não somente se ligam mas, até certo ponto, dependem do ambiente que rodeia os dois homens, pois o reconhecimento do filho só é possível na medida em que este nomeia as árvores que, no pomar, lhe pertenciam. Eis aí um exemplo típico de que, na epopéia, o mundo nunca é apenas palco: "( . . o) o homem faz parte do cenário e o cenário participa da ação" (Schüler, 1972, p. 44).

Portanto, exigir de um poeta épico "alento vital" em sua narrativa (tomando-se aqui essa expressão no sentido, já explicado, de ênfase à subjetividade) é exigir algo que absolutamente não lhe diz respeito, pois ele, de forma alguma, está interessado em narrar elementos subjetivos, mantendo-se concentrado no objeto.

O segundo argumento levantado contra a autenticidade da segunda parte do canto XXIV diz o que segue: "Ulisses, ao encontrar Laertes inconsolável pela morte do filho, deveria dar-seIhe a conhecer imediatamente. Para que lhe contar uma série de mentiras destituídas de interesse? Trata-se de mais uma narrativa para alongar o desenvolvimento" (Dufour e Raison, 1960, p. 323).

$\mathrm{Na}$ verdade, não podemos deixar de reconhecer, nessa atitude de Ulisses, uma certa falta de consideração por aquilo que o pai possa estar sentindo depois de tantos anos de ausência do filho. Mas, nos perguntamos, não devemos ver nessa atitude do herói uma nova manifestação de uma faceta de sua personalidade que, desde o proêmio, ficara bem evidente, ou seja, o desejo de conhecer homens e coisas, satisfazendo, assim, a uma curiosidade muito pessoal? Parece-nos que sim. Não se revelar imediatamente ao pai é a maneira que Ulisses encontrou de conhecer os 
sentimentos que o velho alimentara durante todo aquele tempo em relação à sua ausência e também de presenciar a reação que despertaria em Laertes a menção do filho ausente.

O elemento de inconseqüência que podemos verificar nessa atitude de Ulisses e que não seria de esperar em um homem tão prudente quanto ele pode ser facilmente explicado se nos reportarmos a algo que dissemos antes: Homero não cria tipos e sim indivíduos. E é como indivíduo, como ser cujas reações podem muitas vezes nos surpreender, que Ulisses se aproxima do pai, mostrando que, além de prudente, ele também é um homem curioso, que quer conhecer a natureza das coisas e dos homens e para quem o mistério constitui um desafio.

Outro argumento a que podemos nos referir é este: "O prudente Ulisses toma repousadamente a refeição, em companhia dos seus, sem dar a impressão de pensar, senão já no fim, no perigo iminente" (Dufour e Raison, 1960, p. 323).

A explicação para essa atitude de Ulisses pode ser encontrada no que dissemos logo acima sobre o fato de ser este herói um indivíduo e não um tipo. É como indivíduo que ele, muitas vezes, deixando de lado a prudência que tão bem o distingue normalmente, apresenta-se a nós com outras marcas de caráter, como a que nesse trecho se evidencia: Ulisses é, além de prudente e sábio, um homem que gosta da boa vida, e o comer faz parte dela. Aliás, não é essa a primeira situação em que o comer, interpondo-se no meio das agruras e dificuldades, manifesta-se como um momento de plenitude, de felicidade geral, que merece ser narrado: no canto IX, encontra-se uma situação idêntica.

O último argumento apontado por Médéric Dufour e Jeanne Raison e que visa, assim como os demais, a provar a inautenticidade do canto XXIV da Odisséia, é este: "É de todo inútil o diálogo de Atena com Zeus. A discussão, fora de propósito, entre Ulisses e Telêmaco acerca da coragem, bem como as reflexões de Laertes, raiam o grotesco. O mesmo se pode dizer da luta, que, apenas iniciada por Laertes, é imediatamente suspensa pela intervenção de Atena" (Dufour e Raison, 1960, p. 323).

Quanto ao diálogo entre Atena e Zeus, parece-nos que ele não só não é inútil como, ao contrário, é indispensável no final da Odisséia. Para comprovarmos esta opinião, basta nos reportamos ao canto I e, mais especificamente, ao concílio dos deuses que nele se realiza; os participantes realmente ativos desse concílio - Zeus e Atena - decidem, depois de um diálogo relativamente curto, que já está na hora de Ulisses retornar a Ítaca; em outras palavras; podemos dizer que são esse dois deuses que colocam a ação do poema em movimento. Sendo assim, nada mais lógico do que fazer com que as próprias forças que desencadearam a ação a conduzam também ao seu término - é o que Homero, com toda a pertinência, faz no canto XXIV. Ao nos darmos conta disso, uma pergunta logo se impõe: deveremos ver, então, na Odisséia, um domínio da vontade divina, já que são os deuses que iniciam e que dão fỉm à ação? Obviamente que não. Os deuses, apesar da importância de sua atuação no decorrer de todo o poema, não agem arbitrariamente, sem conhecimento dos planos humanos; ao contrário, através de sua ação inicial, eles apenas ajudam Ulisses a realizar o seu maior desejo, o retorno a Ítaca, e agora, no último canto, ao decretar que a paz seja firmada, Zeus nada mais faz do que novamente auxiliar o herói, dessa vez colaborando para que ele concretize uma aspiração que estava implícita naquele desejo maior acima referido, ou seja, a aspiração a reconquistar o seu antigo lugar de rei de Ítaca.

Com esse diálogo entre Atena e Zeus temos, por assim dizer, o fechamento do círculo que se abrira no canto I: as proposições que nele se haviam colocado chegam a se tornar realidade agora.

Com respeito ao restante do argumento transcrito, a afirmação de que a discussão entre pai e filho sobre a coragem e a interrupção imediata da luta "raiam o grotesco" ignora todo o contexto do poema. No que se refere à coragem, não vimos, desde o início, ser ela um dos valores máximos para o herói? E no que concerne especificamente a Telêmaco, não o vimos, nos primeiros cantos, como um adolescente que está entrando na idade adulta e que, como homem que se está 
tornando, deve se revelar duplamente - como orador e como guerreiro? Ora, Telêmaco já se revelara como orador na assembléia realizada no canto II. Agora é chegado o momento de sua revelação como guerreiro, no campo de batalha, e ele promete ao pai que "este meu coração não maculará o renome de tua linhagem" (Homero, 1960, p. 334). Em consonância com essas palavras está a sua atitude de investir, junto de Ulisses, "contra os guerreiros da primeira fila, dando neles com suas espadas e lanças de dois fios. Tê-los-iam matado a todos e feito perder a esperança de voltarem para a cidade, se Atena, filha de Zeus, portador da égide, não os tivesse detido a todos com um grito" (Homero, 1960, p. 334): A curta duração da luta não nos impede de ver que a formação de Telêmaco, iniciada no canto I, está completa: ele agora é um homem.

Uma palavra apenas quanto ao "grotesco" do final da luta. É bem verdade que é um tanto abrupta a suspensão do combate. Mas, podemos perguntar, de que teria servido o alongamento do mesmo? Ele seria, sem dúvida, uma nova oportunidade de o poeta abarcar a realidade um pouco mais amplamente. No entanto, tornamos a perguntar, será que a realidade que cabia à Odisséia abranger já não se encontrava toda dentro do poema? Entre aqui um outro elemento: a não-subordinação do autor épico ao fim. Mas deixaremos as considerações a esse respeito para a parte referente às conclusões.

\section{Conclusões}

A divisão, nitidamente manifesta, da Odisséia em três partes - Telemaquia, narrações de Ulisses e retorno do herói a Ítaca - é responsável pela idéia de que cada um desses momentos corresponde a um estágio distinto de composição, cuja justaposição e reelaboração por um poeta mais recente teriam dado como fruto o poema tal como hoje o conhecemos.

Dentre as muitas passagens de que se têm valido os defensores dessa idéia para comprovála, podemos salientar o final da Odisséia - particularmente, o final do canto XXIII e o canto XXIV - como uma das mais visadas. Nesse sentido, diz Aubreton: "É no verso 296 do canto XXIII da Odisséia que se vê o verdadeiro fim do poema" (Aubreton, 1968, p. 348). Anteriormente, ele já afirmara: "Todo o fim do canto XXIII e o canto XXIV muitos os consideram como interpolação. As Narrativas a Penélope, a Descida aos Infernos e a cena em casa de Laerte já eram rejeitadas pelos alexandrinos" (Aubreton, 1968, p. 53).

Nessa mesma linha, encontra-se o depoimento de Gilbert Murray: "Nós também sabemos que Aristarco considerava espúrio o último canto da Odisséia e que tanto ele quanto Aristófanes de Bizâncio consideravam o verso 296 do canto XXIII como 'o fim da Odisséia' “(Murray, 1934, p. 296).

Foi nosso objetivo, no decorrer deste estudo, mostrar nossa discordância de tal idéia, procurando comprovar nossa suposição da existência de um estreito vínculo do canto XXIV com o resto do poema e, mais ainda, da imprescindibilidade do mesmo à estrutura da Odisséia .

No que se refere especificamente à vinculação de XXIV aos demais cantos, cremos ter conseguido mostrar que, ao contrário do que dizem os argumentos analisados, não há absolutamente nada de novo no final da Odisséia e que as supostas contradições existentes entre esse final e o restante do poema não passam de elucubrações. Na verdade, os processos de que o autor lança mão, no último canto, são exatamente os mesmos que vinha usando em toda a obra. Nesse sentido, podemos mencionar, em primeiro lugar, as repetições (lembremos que uma das causas de se considerar espúrio o canto XXIV é exatamente o fato de nele se fazer a segunda descida aos Infernos do poema e a terceira referência à tela de Penélope). Essas repetições abundam na Odisséia e, em lugar de serem rejeitadas por estarem em dissonância com o nosso desejo moderno de concisão, devem ser explicadas a partir do contexto em que se insèrem; como 
bem o diz Aubreton, não devemos ver nelas "uma intenção, ou pelo menos, um processo do escritor?" (Aubreton, 1968, p. 59.) O poeta épico sabe quais os trechos que são "apreciados pelo seu auditório" (Dufour e Raison, 1960, p. 10) e, no intuito de satisfazê-lo, não se cansa de repetilos: "Nesta fase primitiva, (...) repetição e recorrência são elementos característicos e altamente valorizados" (Thornton e Thornton, 1962, p. 87).

Em seguida, podemos referir-nos às fórmulas estereotipadas, cujo uso também não se restringe ao canto XXIV mas, bem ao contrário, é comum a toda a épica grega; as razões para esse uso já foram arroladas anteriormente, sendo que, dentre elas, salientamos a possibilidade de, através de tais fórmulas, o autor se fixar no mundo exterior, no mundo do objeto.

Em terceiro lugar, devemos fazer referência a um outro processo homérico que, disseminado por sua obra, se faz igualmente sentir nesse último canto: o emprego de antíteses para a apresentação quer de personagens quer de situações. No canto XXIV, os contrastes dizem respeito especialmente a personagens, e o seu emprego assume proporções bastante grandes, particularmente na cena da descida ao Hades, em que, como vimos, encontramos as oposições Clitemnestra x Penélope, Agamênon-Aquiles x Ulisses, pretendentes x heróis combatentes de Tróia e pretendentes x Agamênon-Ulisses.

Ainda com relação às personagens, não podemos nos esquecer de mencionar a preocupação homérica de, em todos os instantes, apresentar notas caracterizadoras das mesmas, fazendo com que a imagem que o leitor tem delas fique completa. É nesse sentido, por exemplo, que, no canto XXIV, se fala de Hermes como condutor das almas ao Hades quando tal atribuição do deus ainda não havia sido mencionada no poema.

Também com respeito às personagens, observamos que, no último canto, permanece a intenção do autor de não tipificá-las, mas de, ao contrário, individualizá-las sempre. E é por esse motivo que as suas atitudes, ainda nesse final, continuam a nos surpreender, como, por exemplo, a atitude de Ulisses ao se mostrar capaz de prolongar o sofrimento de seu velho pai quando dispõe de todos os recursos para eliminá-lo de vez.

Não podemos deixar de fazer menção à atuação divina no poema, atuação essa que, também no último canto, apresenta relevo. Referimo-nos, em especial, ao diálogo entre Atena e Zeus, o qual, como dissemos anteriormente, nos parece indispensável à estrutura da obra, pois, da mesma forma que foram os deuses os responsáveis pela movimentação da ação, devem ser também eles os responsáveis pelo seu término.

Igualmente pela temática o canto XXIV está vinculado ao restante do poema. Nesse sentido, dois momentos dele devem ser relembrados. O primeiro corresponde ao início do canto, quando os pretendentes chegam ao Hades; essa chegada representa o começo da expiação de suas culpas terrenas - viver no Hades, na sombra, na ausência de luz, é o castigo que eles merecem pelos erros que cometeram. O segundo momento a que pretendemos nos referir é o diálogo entre Ulisses e Laertes; este, ao saber do que o filho fizera aos pretendentes, diz: "Zeus Pai, ainda existem deuses no vasto Olimpo, se é verdade que os pretendentes pagaram sua louca insolência" (Homero, 1960, p. 330). Como bem o salienta Aubreton, nesse trecho "reencontramos toda a teologia da Odisséia resumida em algumas palavras (. ..)" (Aubreton, 1968, p. 349). Esses dois momentos - a chegada dos pretendentes aos Infernos e a fala de Laertes - remetem-nos às palavras iniciais de Zeus no canto I: "(. . .) 'Ah!, de que maneira os mortais censuram os deuses! A dar-lhes ouvidos, de nós provêm todos os males, quando afinal, por sua insensatez, e contra a vontade do destino, são eles os autores de suas desgraças (. . .)' " (Homero, 1960, p. 13).

Em suma, a polaridade erro-punição vincula tematicamente o canto XXIV ao restante da Odisséia. Tal polaridade atinge o poema todo, o que contradiz claramente a hipótese de um crescimento gradativo.

Mas mesmo que tenhamos conseguido mostrar que o canto XXIV está estreitamente relacionado ao resto da Odisséia, tanto no conteúdo quanto na forma - o que vem contradizer a 
opinião de que ele não passa de uma interpolação -, precisamos nos deter um pouco mais na explicação de nossa crença naquilo que chamamos acima de "imprescindibilidade" de XXIV à estrutura da obra.

Para provarmos nossa opinião, devemos nos reportar inicialmente a uma das características mais marcantes da epopéia, característica essa que é sempre mencionada quando desejamos contrastá-la com a tragédia: estamo-nos referindo à não rigorosa determinação do final da epopéia. Embora não possamos negar que isso seja realmente assim e que, enquanto na tragédia tudo converge para o final, na epopéia o fim é flexível e não rigorosamente determinável, cremos que, na Odisséia, essa flexibilidade não é tão grande quanto na Ilíada, cujo autor, como bem o diz Donaldo Schüler, "sem trair os seus propósitos, poderia terminá-la tanto na morte de Heitor como no sepultamento de Pátroclo ou ainda no sepultamento de Heitor, onde agora conclui" (Schüler, 1972, p. 30-1). Não nos parece que o autor da Odisséia, "sem trair os seus propósitos", poderia terminar o poema antes do tempo em que o conclui. É verdade que "a Odisséia canta a história do herói que, depois de muitos entraves, chega ao seu lar" (Schüler, 1972, p. 31), mas não admitimos que "a chegada ao lar deve, portanto, ser o fim do poema" (Schüler, 1972, p. 31). A chegada ao lar, para Ulisses, não representa apenas voltar a pisar no solo pátrio, mas envolve todo um processo de reconquista da esposa e da terra, processo esse que, segundo acreditamos, só fica totalmente concluído no canto XXIV, com a paz firmada entre Ulisses e seus opositores. A importância da paz, nesse poema, é salientada por Maria Helena da Rocha Pereira: “O alvo agora é a paz, e podese dizer que a nostalgia da paz é a sua dominante" (Pereira, 1967, p. 68).

Voltar a Ítaca significava para Ulisses voltar a reencontrar a esposa, o filho, o pai e também voltar a ocupar a posição que lhe pertencia de rei de sua ilha. E não só da perspectiva de Ulisses isso é verdadeiro; Ítaca também estava esperando por ele: a não-realização de assembléias durante os vinte anos de sua ausência (ver, nesse sentido, o canto II) o comprova. Deixar de apresentar Ulisses na reta final de sua volta à antiga posição não seria congruente com o desejo do autor épico de abarcar a realidade total.

Talvez se pudesse dispensar a chegada dos pretendentes ao Hades; afinal de contas, eles já haviam recebido o castigo merecido com a morte. Mas, perguntamo-nos, a idéia da punição não ganhará maior ênfase com esse contato com o mundo dos mortos, com toda a tristeza que dele emana? Acreditamos que sim. Por outro lado, essa segunda descida ao Hades parece ter por fim, como já dissemos, fechar o círculo das oposições de personagens que, desde o canto I, se fazem presentes na Odisséia.

Cremos poder finalizar nossa comprovação da escassa flexibilidade do final da obra em análise valendo-nos de uma idéia emitida por Donaldo Schüler ao se referir aos incidentes paralelos existentes no início e no fim da Ilíada: "O canto XIX, próximo ao fim, corresponde antiteticamente ao canto I" (Schüler, 1972, p. 51-2). Aplicando essa concepção à Odisséia, facilmente concluiremos que também nela o paralelismo de incidentes está presente, só que não entre o canto I e outro "próximo ao fim" mas entre o I e o último canto: esses dois é que são os cantos antitéticos da Odisséia. Senão vejamos; no canto I, Ulisses encontra-se longe da pátria, ansiando por voltar a ela e reconquistar tudo o que, por direito, lhe pertence; no canto XXIV, Ulisses está em Ítaca e tem todos os seus antigos direitos assegurados (inclusive o direito ao trono); no canto I, os pretendentes cometem os excessos já bem nossos conhecidos; no canto XXIV, eles recebem a mais penosa punição para os seus crimes; em I, o concílio dos deuses coloca a ação em movimento; em XXIV, esses mesmos deuses fazem com que tudo termine bem. Ora, Schüler crê na importância dos incidentes paralelos para a estrutura da Ilíada, pois, diz ele, tais incidentes "revelam o plano racional que sustenta o todo" (Schüler, 1972, p. 51). Se isso é realmente assim também para o outro poema homérico - e parece-nos que não podem restar dúvidas a respeito -, "o plano racional que sustenta" a Odisséia só fica completamente visível quando o canto XXIV se encerra. A partir dele, a epopéia poderia ser estendida, como acontece com a Ilíada, que, depois 
de XIX, ainda contém mais cinco cantos; mas terminar antes de XXIV seria subverter o plano global de composição da Odisséia.

\section{Referências Bibliográficas}

AUBRETON, Robert. Introdução a Homero. 2.ed. São Paulo: Difusão Européia do Livro, Editora da Universidade de São Paulo, 1968.

DUFOUR, Médéric; RAISON, Jeanne. Introdução e Notas. In: HOMERO. Odisséia. Tradução por Antônio Pinto de Carvalho. São Paulo: Difusão Européia do Livro, 1960.

HOMERO. Odisséia. Tradução por Antônio Pinto de Carvalho. São Paulo: Difusão Européia do Livro, 1960.

JAEGER, Werner. Paideia; a formação do homem grego. Tradução por Arthur M. Parreira. São Paulo: Herder, s.d.

MURRAY, Gilbert. The rise of the Greek epic. 4.ed. London: Oxford University Press, 1934.

PEREIRA, Maria Helena da Rocha. Estudos de história da cultura clássica. 2.ed. Lisboa: Calouste Gulbenkian, 1967. v.1.

SCHÜLER, Donaldo. Aspectos estruturais na Ilíada. Porto Alegre: Editora da UFRGS, 1972.

STAIGER, Emil. Conceitos fundamentais da poética. Tradução por Celeste Aída Galeão. Rio de Janeiro: Tempo Brasileiro, 1975.

THORNTON, H.; THORNTON, A. Time and style; a psycho-linguistic essay in classical literature. London: Methuem, 1962.

WOODHOUSE, W. J. The composition of Homer's Odyssey. Oxford: Clarendon Press, 1930.

GOETTEMS, Míriam B. Le chant XXIV et l'unité de l'Odyssée. Classica, São Paulo, 7/8: 181-193, $1994 / 1995$.

\footnotetext{
RÉSUMÉ: Il y a longtemps que la thèse de l'interpolation du chant XXIV de l'Odyssée est débattue - et même les grecs le firent - par différents chercheurs. Dans cet article nous allons exposer quelques arguments qui ont été utilisés pour défendre cette thèse et plus spécialement ceux développés par Médéric Dufour et Jeanne Raison dans l'édition de l'Odyssée publiée par la Diffusion Européenne du Livre, en cherchant à les réfuter à travers l'analyse de diverses caractéristiques de l'oeuvre d'Homère présentes dans le chant XXIV. Nous essaierons, ainsi, de montrer le lien étroit de ce chant avec le reste du poème et par conséquent l'unité structurelle de l'Odyssée.

MOTS CLES: Homère, Odyssée, chant XXIV, unité du poème.
} 